Portland State University

PDXScholar

1976

\title{
The negative effects of divorce on the behavior of children
}

\author{
David Hawkins \\ Portland State University \\ Karen Lloyd \\ Portland State University
}

Follow this and additional works at: https://pdxscholar.library.pdx.edu/open_access_etds

Part of the Child Psychology Commons, Social Welfare Commons, and the Social Work Commons Let us know how access to this document benefits you.

\section{Recommended Citation}

Hawkins, David and Lloyd, Karen, "The negative effects of divorce on the behavior of children" (1976). Dissertations and Theses. Paper 1862.

https://doi.org/10.15760/etd.1861

This Thesis is brought to you for free and open access. It has been accepted for inclusion in Dissertations and Theses by an authorized administrator of PDXScholar. Please contact us if we can make this document more accessible: pdxscholar@pdx.edu. 


\title{
THE NEGATIVE EFFECTS OF DIVORCE ON THE \\ BEHAVIOR OF CHILDREN
}

\author{
by \\ DAVID HAWKINS \\ and \\ KAREN LLOYD
}

\begin{abstract}
A practicum submitted in partial fulfillment of the requirements for the degree of
\end{abstract}

MASTER
OF
SOCIAI WORK

Portland State University 1976 


\section{ACKNOWLEDGEMENTS}

We wish to thank Dr. Stanley Cohen, Assistant Professor In the Department of Psychiatry and Pediatrics, University of Oregon Health Sclences Center, and Nolan Jones, Research Assistant, and the other members of the IDCAP project team for their advice and encouragement, and particularly for the use of data from the project, Impact of Divorce on Children and Parents.

We wish to express our appreclation to Dr. John Longres, Associate Professor of Soclal Work and Soclology, Portland State Unlversity, School of Soclal Work, for his assistance in the design of this practicum and for his advice and support in completion of this practicum. Thanks go to Dr. Q. Dean Clarkson for help with the statistical problems, and to Bea Todd for typing this work. 
TABLE OF CONTENTS

PAGE

ACKNOWLEDGEMENTS . . . . . . . . . . . . . . . . 11

IIST OF TABLES . • • • • • • • • • • • • • • • • • • •

CHAPTER

I INTRODUCTION •. . . . . . . . . . . . . . 1

II REVIEW OF THE LITERATURE . . . . . . . . . 3

Causes for Divorce . . . . . . . . . 11

Causes for Divorce Increase

Stressful Marriages

Changing Attitudes Towards Divorce

Statistics on Divorce

Behavioral Changes in Chllaren

Description of Behavioral Changes

Expectations of the Study . . ... . 31

III METHODOLOGY . . . . . . . . . . . 32

Introduction . . . . . . . . . . 32

IDCAP . . . . . . . . . . . 32

Study Questions . . . . . . . . 35

Sample . . . • . . . . . . . 37

Coding and Rellability . . . . . . . 39

Variables . . . . . . . . . . 39

Limitations of the Study . . . . . . 40 
FINDINGS . . . . . . . . . . . . 42

Incidence of Problems . . . . . . 43

Types of Problems . . . . . . . . . 51

Severity . . . . . . . . . . 54

Severity of Problems for Individual Children

Severity of Problems Within

Families

Summary • • • • . . . • . • • 59

V CONCLUSIONS . . . . . . . . . . . 61

Discussion........... . . 61

Implications for Social Work. . . . 64

Recommendations for Future Research . . 65

BIBLIOGRAPHY .. . . . . . . . . . 66 APPENDIX I . . . . . . . . . . . . . . . . 72 APPENDIX II . . . . . . . . . . . . . . . . . 87 


\section{LIST OF TABLES}

TABLE

PAGE

I Incidence of Problem Behavior Among Children . . . . . . . . . . 44

II Incidence of Perceived Problems in

Families . . . . . . . . . . 44

III Sex of Child and Percelved Behavior

Change . . . . . . . . . .

IV Age of Child and Percelved Behavior

Change . . . . . . . . . . . 46

V Economic Status and Percelved Negative

Behavior Change of Children . . . . 47

VI Religious Preference and Perceived

Negative Behavior Change of

Chlidren . . . . . . . . . . . 48

VII Amount of Time Both Parents Spend

Working and Percelved Incidence

of Problems . . . . . . . . . . .

VIII Problems of Children in Families of

Three or More Chlldren . . . . . 50

IX Incidence of Problems in Health, Inter-

personal and School Categorles . . . 52

X Incldence of Health Problems . . . . . . 52 
TABLE

XI., Incidence of School Problems . . . . . . 53

XII Incidence of Interpersonal Problems . . . 54

XIII Incidence of Perceived Severe and

Not Severe Problems . . . . . . 55

XIV Incidence of Severity Ratings of

Children as Perceived by

Parents . . . . . . . . . . 56

XV Sex of ChIld and Percelved Severity

of Behavloral Change . . . . . . . 56

XVI Age of Child and Percelved Severity

of Behavioral Change . . . . . . . 57

XVII Incidence of Percelved Severity in

Families . . . . . . . . . 
CHAPTER I

\section{INTRODUCTION}

Divorce is becoming a common event in the lives of many people. It is now easier to dissolve marriage and less stigma is attached to divorced people. However, for many, divorce remains a negative and traumatic experience. Not only does the divorcing couple suffer, but the chlldren are affected as well.]

In the past, concern has been focused on the problems of the parents, but lately there has been a growing interest in the effects of divorce on children. This has especially been the case among those in the helping professions who work with children experiencing problems. Because of their personal interest, the writers became members of a research team studying divorce. The project, "Impact of Divorce on Children and Parents," (IDCAP), dealt with several areas of family life affected by divorce. The study presented here derives from one particular area of that effort.

Our study is concerned with the effects of fling for divorce on the behavior of children. We are interested in the adjustment of the child to the changes which occur during separation and divorce, and we maintain the attitude that the lives of children are affected in some way when a 
marriage or family unit dissolves. A generally accepted bellef is that divorce produces negative consequences in the lives of children as shown in their behavior. However, recently a number of studies have suggested that divorce need not be a negative experience, at least to the degree most people feel it is. ${ }^{1}$ Factors that influence the effects on children include: the intensity of the conflict between the divorcing partners; the degree to which parents demonstrate concern for the chlldren and help them prepare for the separation; the child's attachment to the custodial parent; and the level of maturity and general personality characteristics of the child.

The primary goal of the study presented here is to determine the extent to which negative behavior changes in children are visable immediately following a divorce. Add1tionally, we wish to describe those changes and determine their frequency. Finally, we w1sh to relate such changes to certain social variables including economic status and age and sex of the children.

${ }^{1}$ J. Loulse Despert, Children of Divorce (Garden City, New York: Dolphin, 1962). 
CHAPTER II

REVIEW OF THE LITERATURE

This study is concerned with family and children. As a background, and in order to help in the analysis of data, this chapter will examine the family as an institution, as well as changing attitudes toward divorce. The research concerning possible negative behaviof changes in children due to divorce is central to our study.

Little is known about family organization before the beginning of written history. The variety of familial structures found in earlier times or among nonindustrial people gives us a number of insights but does not tell us about the origins of the American family. All statements about the origin and evolution of family types must be classified as supposition. 2

* The family is generally composed of parents and their children. The conjugal or nuclear family refers to an int1mate, closely knit group consisting of spouses and offspring, whereas the consanguine or extended family consists of a large group of blood relatives. A basic assumption of

2 Ralph Linton, "The Natural History of the Family," in The Family: It's Function and Destiny, ed. by Ruth $N$. Anshen (New York: Harper \& Bros., 1959), p. 31. 
the family is the continuity of the mated relationship and the anticipation of permanence.

Man's need for security in his personal relationships and a desire for congenial companionship had probably given considerable permanence to matings before cultural factors came into play. One of these factors is that labor has generally been divided according to sex. Historlcally, the man has been the provider and the woman the preparer of raw materials, until recently when this basic pattern of economic interdependence of the sexes has begun to change. In Western cultures, the women's movement has had an effect on liberating the house-bound female and allowing her to work outside the home in the economic system.

Although the mating relationship provides a basis for the family unit, other relationships are also involved, such as those of parents to children and children to each other. Many have seen the function of the family as that of the parents providing for the emotional and psychological needs of the children. On the other hand, Laing writes that the family's functions are

- to Induce a false consclousness of security - to promote respect, conformity, obedience; to con children out of play; to induce a fear of fallure; to promote a respect for work; to promote a respect for respectability. 3

${ }^{3}$ R. D. Laing, "The Mystification of Experience," in Radical Psychology, ed. by Ph11 Brown (New York: Harper \& Row, 1973); p. 117. 
In opposition to the feeling that the family's function is supportive and growth-producing for the children, Laing feels that it is inhibitive and growth-denying. It is likely that family life includes both functions.

Various forms of the family unit have been found other than those already mentioned, such as group or plural marriages, plurality of husbands or wives, single parent families, etc. Societies using forms of plural marriages have not been uncommon. Polygamy, plurality of wives, is much more common than polyandry, plurality of husbands. Even in socleties which consider these the ldeal form of marriage, most families are monogamous through force of circumstances. ${ }^{4}$ In our culture, single parent families are becoming more common and accepted.

The early Western family organization, associated with a pastoral economy, was patriarchal (general control of family members by the father), patrilinial. (descent is traced through the males), polygamous (plurality of wives), and extended ( $a$ residential combination of three or more generations or relatives). In the Hebrew family, the patriarch had almost absolute power. Women were subjected to the will of their husbands, and sons were highly valued. Greek fam1lies were very similar; however, they were monogamous. Women were still of low status. Men were able to divorce ${ }^{4}$ Linton, op. c1t., p. 40. 
their wives in various methods depending on the culture, and only gradually were the wives permitted to divorce their husbands for limited reasons. Like their predecessors, the Germanic and English peoples were patriarchal, but the system of double descent protected the wives from too much abuse. However, there was also a double standard of moral1ty, favoring the males.

The emergence of feudalism emphasized ab1l1ty to bear arms and lowered the status of women even more so. This attitude was gradually replaced as the romantic tradition of chivalry appeared; and though at first it was considered incompatible with marriage, it grew to be more popular. The lingering effects of this tradition were transposed to the American colonies and the family system was organized around the nuclear or confugal family with a clearly patriarchal system. Early America was characterized by rural 1iving. Families settled on a plot of land. Their subsistence came from reaping the harvests and maintaining their animals. That was the era of the productive family system. As industrialization progressed, families moved closer to sources of employment and the significance of working the land diminished. People looked for work in towns and cities, until currently the city is the focal point of most American families. With the passage of time and widespread mobli1ty, the patriarchal tradition weakened, until finally, industrialization and urbanization 
transformed the family into a small consumption unit. 5 We will discuss later the functions of the family that changed during this period.

Customs of the family often correspond with the customs of their soclety. For example, when the government is authoritarian, the family head tends to reflect this. The American family is relatively nonauthoritarian; however, men st111 have authority over many family matters including place of residence. In our culture, free enterprise influences many of our social customs, including the way the family is established. We are encouraged to choose our own mates but the allenation of the free enterprise system influences us to treat others, including marital partners, as objects and to measure their personal worth as our own in terms of individual achievement. Factors influencing selection of a mate are: (a) educational and economic factors, causing people to walt longer before marriage; (b) Increased moblilty with a wider selection of mates possible; and (c) an increased emphasis on romantic love, which is felt to be determinable by the couple alone.

After marriage, the couple is able to make many cholces, a freedom which is unusual in the world. They are free to choose how and where they w11l live, and if they w11l bear and ralse children. It is not uncommon for both

${ }^{5}$ Gerald R. Leslie, The Family in Social Context (New York: Oxford University Press, 1967), p. 211. 
partners in the upper and middle strata to work and pursue careers. It is more common in lower class famllies for the wife to remain at home to care for the children and husband. A notable feature of the American family is its relatively nonauthoritarian character. The mother's opinions are somewhat equal to the father's, and the chlldren are not likely to see them as a last authorlty from which there is no appeal. 6 These free cholce and nonauthoritarian aspects of the family, along with its privacy and potential leisure, evidence only a few of the many ways in which it has become consistent with major emphasis in our national ilfe. 7

The American family which occurs most often is perhaps best characterized as an open, multilineal, conjugal system. Our system is distinctive because of the absence of any important units which cut across conjugal families. The system is made up exclusively of interlocking conjugal (or nuclear) families. ${ }^{8}$ These are individual differences, such as another adult or child outside the immediate nuclear fam1ly living with a family. However, the most commonly found varlance is the single parent family, which involves one


The Family: It's Function and Destiny, ed. by Ruth $N$. Anshen (New York: Harper \& Bros., 1959), p. 60.

$$
7 \text { Ibid. }
$$

8 Talcott Parsons, "The Social Structure of the Family, "In The Family: It's Function and Destiny, ed. by Ruth N. Anshen (New York: Harper \& Bros.; 1959), p. 242. 
parent and the children of the former marriage. This type is not only becoming more common, but more accepted.

The basic satisfactions that family life offers the partners who enter into the marital relationship are the fulfillment of various psychological needs. They may be summarized as the need for affection, security, perfected emotional response, as well as sexual satisfaction. When children are part of the family, it is more often because the parents want them, and the functions of the family expand. A number of people have concelved theorles regarding these functions, and vary somewhat.

Structural functional theory is concerned with the relationship between social organization and function or purpose. Murdock, 9 a structural functionalist, lists four functions common to the family unit: sexual, economic, reproductive and education (or soclalization), while Kingsley Davis, another functionalist, considers reproduction, maintenance, soclalization and placement the primary functions. 10

The structure-function theory focuses on the integration of the family system with the occupational system; ${ }^{11}$

${ }^{9}$ C. C. Harris, The Family: An Introduction (New York: Praeger Publishers, 1967), p. 93.

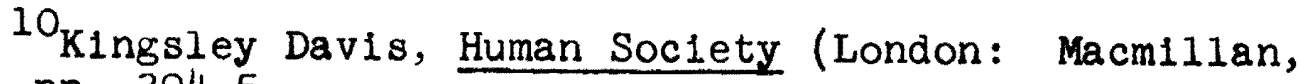
1948), pp. 394-5.

11 Leslie, op. c1t., pp. 248-9. 
how each contributes to the maintenance of the other. W1th regard to American families, ties with the parental generation are minimized, and there is a lack of larger kinship groups. Marrlage is the structural keystone of the system. Procreation, control of sexuality, religious indoctrination, and socialization all lead people into marriage. The occupational system regulates the segregation of roles, requirIng that only one member, the husband, be a full participant in the occupational system. The family must be geographically and socially mobile.

The family has often been concelved of as a passive agent in soclal change--to adopt to changes in other areas of society rather than to cause changes. The economic and political institutions are felt to change more rapidly than the family. Attempts have been made to understand the relationship of the family system to other social institutions. Carle Zimmerman developed a cyclical theory, finding three recurring family types: the trustee, domestic or atomistic family.12 He finds change occurs in giant historical cycles.

The "progressivist theory," as Ogburn describes it, finds technological development as the prime cause of social change and the family as passively adjusting to outside

$$
12 \text { Ibid., p. } 223 .
$$


changes.13 Many functions formerly performed by the fam1ly have been lost to other societal institutions. Functions such as economic, protective, religlous, recreational, educational, and status are no longer held primarily by the family. However, affectional and personality functions are more important than they used to be.

These theories have attempted to describe reasons for a changing family system, which is demonstrable by many factors, one of which is a rise in divorce rates in recent years. The causes for this particular phenomenon are the same as for other soclal changes and will be described later.

\section{Causes For Divorce}

There are many external factors that have added strain to the marriage and family relationships, causing divorce to increase. George Leonard describes other basic reasons for people's inability to get along with one another by writing:

We can orbit the earth, touch the moon . . and yet this society has not yet devised a way (though love propels our very existence) for man and woman to live together for several stralght days w1 14 any assurance of harmony and personal growth. 14

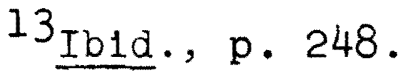

14 George B. Leonard, "The Man and Woman Thing," Look, December 24, 1968, p. 55. 
One of the most common reasons people give for divorce is "incompat1bility." When broken down, this word signifles an abundance of different perceptions and expectations on the part of the couple. Jourard says, "people commonly marry in a haze. They marry an image, not a person. ${ }^{15}$ Later the couple becomes aware of the many differences between them. If not dealt with properly, these differences may grow, 1solating one person from another. Communication may break down under this tension, increasing this isolation. Often there are major problems or differences that are not worked through. Some of these include financlal difflculties, sexual adjustment, religious bellefs, and social class values as well as parenting styles.

Perhaps beneath this array of problems facing a marrlage is another allment: that of allenation. O'Ne1l says, "closeness is a paradox, longed for but increasingly intolerable."16 People do not know how to be intimate, or "they are not sufficlently knowledgeable to tolerate authent1c encounters w1th supposed intimates."17 The fear of intimacy often eventually causes couples to become increasingly

${ }^{15}$ Sidney M. Jourard, The Transparent Self (New York: D. Van Nostrand Company, 1971), p. 43.

${ }^{16}$ Nena and George O'Neil, Open Marriage (New York: Avon Books, 1972), p. 31 .

17 Ib1d., p. 32. 
independent, losing important common bonds and interests, thus setting the stage for divorce. Adding to this sense of allenation may be the role of the family as an institution, such as the establishment of sex roles, and authority patterns whlch generate conflict.

other forces affecting divorce are larger than the problems of individuals. Free enterprise teaches us, as a soclety, to treat each other as objects; socletal authority patterns, and social movements, such as the women's movement, cause conflict between people. Perhaps for some the system is not utilized or integrated properiy.

Causes For Divorce Increase. Individual differences are being less tolerated than in previous decades. When coupled with increasing external pressures placed on the family, the result is an increase in divorce. Understanding the reasons couples divorce will provide a valuable background for this study. We will examine soclal pressures and changing attltudes toward it which affect the increase in divorce.

There is no doubt that the two major wars of our time and the more localized wars have had a disturbing influence on human relationships, even at the most intimate level of association. There is some evidence that family disruption tends to parallel world disruption and that wars bring an 
increase in divorce, whereas peace restores family stability. 18

Another major turmoil that had its onset in the last century was industrialization, which has had a profound impact on people. The introduction of machinery into the field of economic production has resulted in major changes throughout the whole industrial world. Existing industries have been transformed while many new ones have been created. The substitution of mechanical for physical power has caused the rearrangement of the forces of production and redistribution of the population. People are more moblie than ever before, making it difficult for the family to maintain a strong support system. Mobility has had an effect on the family, with 1ts being smaller and less sturdy than in the past. This makes the family more vulnerable to disruption. As has been stated, because of industrialization, blocks of people moved to the city. We have seen the rise of the modern industrial city, and felt the pains of urbanization. The increased productivity of labor and capitol has made possible the rapid accumulation of wealth. These revolutionary changes in wealth have complicated every form of social activity and created a multitude of new problems. Deep and fundamental changes in the industrial basis of soclety have effected and been accompanied by

${ }^{18}$ Paul Jacobson, American Marriage and Divorce (New York: Reinhart and Co., Inc., 1959), p. 91. 
transformations in the social order. With the change in the material basis of existence, the functions of social institutions change in form. The periods of most rapid modern industrial development colncide with the periods of most rapid increase in divorce rates.

As stated earlier, at the beginning of the modern era, the family was the economic unit of soclety. It was usually large and lived close to the soll, functioning as an economic unit, with each member of the family contributing according to his ability. If there existed incompatibility between husband and wife, the care of the children and the economic necessities of the family offered an incentive for adjusting or suffering the difficulties. However, today we see the home maintained more as a comfort and luxury than as a necessity. Census Bureau statistics show young people are postponing marriage until they are older, and families are smaller. 19 Because of the decreased importance and dependency upon the family, economic reasons have not proved sufflclent to hold the family together, and the divorce rate. has registered the result.

Another change that has affected the status of the family is the decline in authorlty of the husband and father. Whereas the man once had complete authority over the home and family, women are beginning to share in

${ }^{19}$ Ann Blackman, "Statistics Project More Stability For Future Marriages," The Oregonian, February 5, 1976. 
decisions regarding the home. The women's movement is largely responsible for this change. For so long, societal pressures locked women into the role of mother and housewife. Recently these traditional roles have been questioned and challenged, resulting in increased employment by women outside the home, and increases in legal, educational, and civic rights of women. With this new emphasis on equality, the trend is for married women to acquire more responsibilitles outside the home, and for married men to assume more responsibilities within the home, so that the sexes share more activities.

The effects of increased employment of wives on family Iife are manifold. With the possibility of economic secur1ty in a job, women have more freedom in the choice of a mate and in the decision as to whether to continue in an unsatisfactory marriage. It is suspected that this new freedom is reflected in divorce rate increases, in that women are exercising this freedom to leave bad marriages. The role of marriage in the life of a woman is greatly modifled. It is not as exclusively important as it used to be. The women's movement is a cause for divorce increase in that it has given women permission to strive for their own 1dentity outside the home, primarily through employment, and to strive for personal happiness even at the risk of dissolving an unhappy marriage. 
Until the mid-nineteenth century, divorce was almost solely the prerogative of the husband. Infidelity and desertion remalned a woman's main grounds for obtaining a divorce. Aware that thelr only means of sustenance was in marriage, women quietly endured their injustice until industrialization provided emancipation. As they left the kitchen for the office or factory, they were no longer content to endure cruelty or general unhappiness. This represents a new attitude toward marriage, and has resulted in dissatisfaction with those marriages which would have been regarded as successful a half century ago.

As has already been mentioned, there is a greater expectation for happiness in marriage and an increased emphasis on the romantic aspects of marriage. There has been a new awareness that marriage can be happy and satisfying, and this quality has come to be expected. The whole basis of marrlage has changed from one of survival to one of pleasure and satisfaction. There is an increased dependency upon love to provide stability in family relations and a changed appreclation of sex and its correlated sentiments. W1th these changing attitudes and expectations from marriage, disappointments arise when marriage cannot fulfill all these expectations and the divorce rate increases.

Another important factor undoubtedly adding to the

increase in divorce has been the changing divorce laws. Although it is difficult to determine whether or not there 
has been an increase in marital dissatisfaction, we can positively identify the removal of barriers to obtain a divorce. In 1967, the National Conference of Commissioners on Uniform State Laws received a grant from the Ford Foundation to look into adapting family law. The effect of their recommendations concerned reducing divorce to a legal recognition that a marriage has in fact broken down. On the basis of these recommendations a uniform law was drawn up to serve as a pattern for several states, with the goal being the no-fault divorce. "The reason why they cannot live together is of no concern to the world; it is no one's business but theirs."20

Societal change is rapid and affects roles that individuals have in marital situations and other aspects of their lives. Roles are in a state of transition, making interpersonal relationships somewhat more confusing and delicately balanced. With the changes in roles, there has come to be an acceptance of the possibility of divorce if the marriage does not bring happiness. With the acceptance of that possibility, divorce loses its emotional qualities, such as the feeling of fallure or guilt, which tends to restrain the individual. With these restraints loosened, people feel freer to separate or divorce. Possibly what is needed is variation in the form of marriage. "With the

${ }^{20}$ Paul Bohanan, ed., Divorce and After (Garden C1ty, New Jersey: Doubleday and Company, Inc., 1970), p. 14. 
growing flexibility of marriage we can expect more alternatives, not as deviations but as acceptable styles."2l With added flexibility in marriage, people will have more choices In the type of family structure than now exist, thereby helping people to live more happlly.

Stressful Marrlages. The process of most marital conflicts that terminate in divorce entalls emotional divorce, physical and finally legal divorce. Emotional divorce is difficult enough but may be bearable if the couple continues to live together. The pain over the dying marriage intensifies when physical divorce (separation) takes place. It is then that feelings of gullt and fallure become overwhelming. Legal divorce tends to come as an emotional afterlude. The legal transaction that accompanies the dissolution of a marrlage does not destroy families. The damage has already been done by the time soclety gives its divorce decree. Goode found that divorce is preceded by a long period of conflict and that the obtaining of a divorce is the final result of a decision process lasting nearly two years. 22 It would seem that in most instances it is the marriage that is most stressful rather than the divorce process 1tself. Similarly,

${ }^{21}$ Helena Z. Lopata, ed., Marriages and Familles (New York: D. Van Nostrand Company, 1973), p. 402 . 22 William J. Goode, After Divorce (Glencoe: The Free Press, 1956), p. 137 . 
divorce may play less a part in the behavior change of children than some marital conflict. A study by Browning of delinquent and nondelinquent boys in Los Angeles led him to the conclusion that "delinquents are as likely to come from homes where a great deal of conflict exists but are structurally unbroken as they are from broken homes."23 These results point to the fact that the negative impact of divorce upon children may be no greater than would be the effects of parents continuing to live together in an unhappy marrlage. Several studies have shown that unhappy unbroken homes may have more deleterious effects upon children than do broken homes. 24

The divorce itself is often not the most stressful part of the marriage. Often it has been preceded by years of turmoll and hostility. The divorce process in fact, is of ten a relief to participants, an end to the conflicts and confusion. Divorce can be a process that can end unhappy, harmful situations.

Changing Attitudes Toward Divorce. It was not long ago that "divorce" was an act, not often publiclzed. It was not discussed because of social custom, religlous

${ }^{23}$ Charles J. Browning, "Differential Impact of Family Disorganization Upon Male Adolescents," Social Problems, Vol. 8 (Summer, 1960), 48.

24 Ivan F. Nye, "Child Adfustment in Broken and in Unhappy Unbroken Homes," Marriage and Fam1ly Living, Vol. 19 (1957), 356-61. 
principles, and historical tradition. There has been an overwhelming effort throughout history to protect marriage and limit divorce. Religlous and social institutions along w1th legal complications, formed a combined barrier to divorce. What may have been started by the church was continued by the newspapers. There has been a pervasive and positive image of marriage and a negative image of divorce protrayed by the mass media." Even in the early twentleth century, public attitudes on divorce were deeply affected by newspapers, magazines and popular books. 25

The state, a silent partner to marriage, has been another opposing force of divorce. Unt1l recently, chaotic and inconsistent divorce laws were widespread, confirming and reinforcing the characteristic American antidivorce tradition. Although divorce was permitted, it was surrounded by inhibiting negative associations.

More recently, marrlage has been viewed as "no longer a stable situation held together by the consensus of a soclety that sees the 11 felong union of man and wife as a desirable institution."26 There is a general feeling that man is not subordinate to the institution of marriage. We

25 Robert K. Merton, "The Self-Fulfilling Prophecy," in Soclal Theory and Soclal Structure (Glencoe: The Free Press, 1949).

26 John H. Snow, On Pilgrimage: Marriage in the $70^{\prime} \mathrm{s}$ (New York: The Seabury Press, 1971), p. 95 
are seeing a "greater expectation of happiness in marrlage,"27 and marriage lasting for the duration of happiness, rather than "'til death do us part."

It is apparent that general socletal attitudes are changing, becoming more accepting of the institution of divorce. This may be observed by relaxing legal codes on divorce, or hearing the decrease in public outcries at the rate of divorce. There seems to be a changing attitude that divorce can be a potentlally liberating experience which restructures family iffe, and is not necessarily detrimental to those involved.

Statistics on Divorce. The number of divorces in the United States is rising every year. However, it must be remembered that the population generally has increased, and could account for some of the increase in divorce. In 1974, the number of divorces grew to 970,000 , an increase of nearly 300,000 annually in nine years. 28

It is interesting to note that the Pacific states, which include oregon, have the highest rate of divorce in the United States, $\int$ with the lowest rate occurring in the Middle Atlantic states. The Pacific states average 5.7

27 W. F. Ogburn and M. F. Nimkoff, Technology and the Changing Family (Boston: Houghton Miffiln Company, 1955), 28 U.S. Department of Commerce, Bureau of the Census, Statistical Abstract of the United States (Washington, D.C.: Government Printing office, 1975), p. 67. 
divorces per 1,000 people, with the state of oregon having nearly 12,000 divorces in 1973.29

Because of the increase of divorce, the number of children involved in divorce is also rising. In 1971, there were 946,000 children involved in divorce, suggesting there are over a million children now involved in divorce annually.30 There is an average of 1.22 children of every divorce decree.

Behavioral Changes in Children

Children often exhibit the stresses and strains of disturbed marriages and divorces in varlous ways, and for various reasons. We have attempted to point out that the bad marriage relationship can be as disruptive to a child as any divorce process, and in fact is often more detrimental to children. A phenomenon which accounts for why certain children show symptoms and not others is that of scapegoating. This idea holds that children are often involved in the tensions between their parents. The parents, by projecting their conflicts on the child, malntain a reasonably harmonlous relationship, although the cost to the

${ }^{29}$ Ibid., p. 67.

30 Dan Golenpaul, ed., Information Please Almanac (New York: Macmillan, 1974); and U.S. Department of Health, Education, and Welfare, Public Health Service, Vital Statistics of the United States (Washington, D.C.: Government Printing Offlce, 1975), Vol. 3 . 
child's development may be great. 31 Therefore, one child may be selected to "bear" the problems which Involve the parents, or the entire family.

Numerous reports have maintained that the broken family leads to a varlety of problems, including crime, delinquency, mental 111ness and a heterogeneous mass of $111 \mathrm{~s}$ afflicting individuals and socletal institutions as a whole. 32 However, others reflect reservation about assertions that divorce per se is bad for children.] One author states that 1t may be true that children from happy marriages are better adjusted than children from divorced homes. However, chlldren from divorced parents are happler than children coming from intact unhappy homes. 33 In our study we will be examining the effects on children coming from unhappy homes that have been divided.

Goode (1956) questions the assumption that divorce leads to poor adjustment for children, although he was concerned that the missing parent would not be an adequate role model to his/her children. He states that "the best facts justify our repeated insistence that the relationship

31E. F. Vogel and N. W. Bell, eds., "The Emotionally Disturbed Child as the Family Scapegoat," in The Family (New York: The Free Press, 1960).

32 Sydney H. Croog, "The Family as a Source of Stress," in Social Stress, ed. by Sol Levine and Norman A. Scotch (Chicago: Aldine, 1970).

$33 \mathrm{~J} . \mathrm{R}$. Udry, The Social Context of Marriage, 2nd ed. (New York: J. B. Lipplncott, 1971). 
between divorce and other behavioral problems of children are not clear."34 others support the idea that divorce is not inevitably a traumatic experience, and in fact can lead to changes for the better. 35

Although divorce does not have to be a traumatic experience, it often is. Children of divorce are often caught in the middle of an unpleasant situation. Westman et al. (1971) state that children from divorced families generally indicate somewhat greater signs of maladjustment than those from intact homes. Other findings dispute this, however. It has been shown that children in broken homes show less problem behavior and better adjustment to parents than do children of unhappy intact homes. 36 There is evidence showing that children are better off living with one parent than the children of unhappy intact homes characterized by bitterness, fighting and physical and mental cruelty where the parents stay together for the children's sake. 37

${ }^{34}$ William J. Goode, Women in Divorce (Glencoe, Ill: : The Free Press, 1956).

35 Susan Gettleman and Janet Markow1tz, The Courage To Divorce (New York: Simon and Schuster, 1974); and Despert, 10c.c1t.

${ }^{36}$ Judson Land1s, "The Trauma of Children When Parents Divorce," Marriage and Family Living, Vol. 22 (1960), 7-13; and Nye, 1oc.c1t.

37 Jane Burgess, "The Single-Parent Famlly: A Social and Psychological Problem," The Family Coordinator, Vol. XVIX (1970), 2 . 
There is supporting evidence that the disturbed marriage can be as disruptive and harmful for the child as the divorce experience. 38 others have found that the broken family is not the vital factor in children's lives it was thought to be. 39 We suspect that it $1 \mathrm{~s}$ the trauma that is experienced before the divorce takes place.

Description of Behavior Changes. It has been noted that children do exhibit various changes when confronted with divorce. We expect to find that some children will exhibit negative behavioral changes while others positive changes. Landis (1960) found the effects of divorce on children vary a great deal according to the age of the child and the way the child viewed his relationship with his parents prior to the divorce. H1s results indicated that it is less traumatic for younger children while those who percelved the home as happy, experlenced a greater degree of trauma.

Despert (1953) designates several feelings that a ch1ld w1ll initially experlence when faced with the parents' divorce. We will be looking for these same feelings and behaviors in our study. The child may experience hostility

38 Judson T. Landis, "Soclal Correlates of Divorce or Nondivorce Among the Unhappy Marrled," Marriage and Fam1ly Living, (May, 1963), 178-9.

39 Lee Burchinal, "Characteristics of Adolescents from Unbroken Homes and Reconstituted Families, "Journal of Marrlage and Family, Vol. 26 (1964), 44-51. 
against one or both parents, guilt feelings, and the paramount feeling of fear. The child of ten reacts in numerous ways. Grief may be shown openly, or the child may flatly reject the reality of the divorce. He may deprive himself of food, refusing to eat, or of pleasure, refusing to play. He may behave in a general negative way, making a nuisance of himself. Some children may show more independence to compensate for an inner need to be dependent. They may be eating or sleeping poorly, having trouble completing tasks, Including schoolwork. Often this is a reaction of preoccupation with the traumatic event. Listlessness and 1rritability may be observed. The child may regress and become fearful of things he hasn't been afraid of for years. He may develop nightmares or make more frequent use of daydreams.

Bowlby (1961) feels that some of the main feelings the child experiences are separation anxiety, rejection and extreme feelings of helplessness. Sugar (1970) agrees with these findings, but also includes feelings of depression, irritablity and sulcldal 1deation. The child may have times of insomnia, skin excoriation, loss of interests and loss of appetite. He also feels that most children are intially angry, frightened and hurt and let their parents know by this acting-out behavior.

T McDermott (1970) states that children experience depression, but the depression may be observed in accident- 
prone behavior. ${ }^{*}$ The child may be blaming himself for the parents' separation, therefore feeling a need to punish himself. The grief may be overwhelming. McDermott also notes a frequency of children running away from home, an attempt to leave the situation while letting their feelings be known.

Grollman (1969) found chlldren who are often host1le to parents act out feelings of frustration and anger. He adds that children experience panic and confusion as well. Gardner (1964) also notes depression in children, and a tendency to withdraw. These are thought to be symptoms of hopelessness and frustration over the separation of parents. Children also display apathy, insomnia and anorexia, ind1cating the child's preoccupation with the stressful event. Gardner has also observed children running away, acting out and throwing temper tantrums, feeling that these signs of anger are inevitable reactions to divorce. He believes that nightmares are a manifestation of repressed hostility. These writers basically agree that nightmares stem from subconsclous material, possibly anger.

Several authors have noted an excess of enuresis in children experiencing a divorce. 40 Morrison (1974) found 40 Irving $R$. Stuart and Lawrence $E$. Abt, Chlldren of Separation and Divorce (New York: Grossman Publishers, 1972). 
enuresis twice as often in children of divorced parents as in chlldren of intact families, while Douglas (1970) notes "an excess" in chlldren of divorcing parents. This problem is felt to be an acting-out behavior that explicitly tells of the child's unhappiness. Often this behavior is assoclated with other regressive, immature behaviors suggesting the child is again seeking attention and wanting to be dependent. 41

Littner (1973) noted self-defeating behavior which, similar to accident-proneness, is felt to be a symptom of depression. Westman (1972), in concurrence with others, noted depression and grief in chlldren as a reaction to the divorce. They often have feelings of helplessness, and are not able to concentrate on what they are doing. They may have thoughts of wanting to hurt, either themselves or their parents.

*

Several studies have shown a relationship between juventle delinquency and divorce. ${ }^{42}$ Again, this is felt to be acting-out behavior, a demonstration of the feelings the

${ }^{41}$ Jane W. Kessler, Psychopathology of Childhood, Englewood Cliffs, New Jersey: Prentice-Hall, Inc., 1966) p. 119.

${ }^{42}$ S. Glueck and E. Glueck, Unraveling Juvenlle Delinquency (Cambridge: Harvard UnIversity Press, 1950); J. F. McDermott, "Divorce and Its Psychlatric Sequalae in Children," Archives of General Psychiatry, Vol. 23 (1970), 42127; and C. A. Whitaker and M. H. MIller, "A Re-evaluation of Psychiatric Help When Divorce Impends," American Journal of Psychiatry, Vol. 126 (1969), 611-18. 
child has about the divorce. Delinquency is considered a severe form of acting-out behavior. Juvenile delinquency most often refers to offenders who are younger than the statutory age limit, which varies from sixteen to twenty years. A child adjudged a delinquent may have committed an act for which an adult would have been adjudged a criminal, or his offense may be one which is not applicable to adults (i.e., Incorrigibility, waywardness or truancy). 43 Delinquency is often aggression turned outward, toward rules of society, the authorlty of a parent, or another individual. It has been noted that delinquents of ten have large quant1ties of hate, often stemming from the personal problems going on in their lives. 44 This study observed delinquency may be a reaction to the divorce taking place in the home. However, Despert (1953) cites a study by N. C. Elmer which revealed that only one-tenth of the delinquent boys and one-fifth of the delinquent girls came from families broken by actual separation and divorce. We see that the relationship between divorce and delinquency remains unclear, and warrants further research.

43 Kessler, op. c1t., p. 20.

44 Fritz Redl and David Wineman, Children who Hate (New York: The Free Press of Glencoe, 1951), p. 20 . 
Expectations of the Study

This study will examine and document negative behavloral changes in children as percelved by parents. To the extent that negative behavioral changes exist, the soc10economic, demographic and interpersonal correlates of the changes w1ll be analyzed. Hopefully the study w1ll add to the literature in this area by further documenting the likeIlhood of negative behavior changes, the varlous types of negative changes to be expected, and the correlates to the changes. 
CHAPTER III

METHODOLOGY

\section{Introduction}

We have been interested in children and divorce. When It came to our attention that a research project had recently begun studying the effects of divorce on children, we jolned the staff, interviewing parents and collecting data. Selected data from that project, IDCAP, comprises the basis of this paper.

\section{IDCAP}

The research project titled "The Impact of Divorce on Ch1ldren and Parents" was developed by Dr. Stanley N. Cohen. It is a collaborative effort between the clackamas county, Oregon Circuit Court and the Portland State University National Criminal Justice Educational Development Project. It has been funded by LEAA funds administered by the Portland State University Division of Urban Affairs. The grant is part of the Criminal Justice Educational Development Project.

The major aim of this two-year study is to examine the Impact of divorce on the personal and social adjustment of minor children. Of particular interest is the extent to 
which children exhibit delinquent behavior prior to, during, and after the divorce of their parents.

The sample population consisted of divorcing couples who had not previously married, who had minor children, and who reside in Clackamas County, Oregon. The project gathered data from both divorcing parents, their chlldren, attorneys of record, school and Clackamas County Juvenile Court staff, as well as court and school records. It was planned to be gathered at three time perlods: at the time of fling, six and elghteen months after the filing. The IDCAP. project was directed by $\mathrm{Dr}$. Stanley Cohen, Assistant Professor in the Department of Psychiatry and Pediatrics, University of Oregon Medical School, and Nolan Jones, Research Assistant.

The project objectives as noted in the proposal are:

a. A comprehensive descriptive analysis of the demographic and attitudinal characteristics of a random sample of first married divorcing couples with minor children.

b. A descriptive analysis of the factors considered by courts in determining custody in noncontested cases.

c. A descriptive analysis of those soclal and personal factors operating with a family that prompt intervention by courts in determining child custody.

d. An eighteen month longitudinal study to the extent to wh1ch parenting styles developed by 
couples prior to, during, and after divorce, affect the psycho-social development of their children. 45

With regard to these objectives, the major independent varlables are whether the children were prepared for their parents' divorce and the type of parenting styles developed by the divorcing couple. The major intervening varlables are social class and cultural attributes (income, occupational status, race/ethnicity, religlous orientation).

IDCAP's hypotheses as noted in the project overview are :

1. Children whose parents have prepared them for divorce and have established a cooperative parental style will exhibit the best developmental adjustment of any group of children involved in divorce.

2. Ch1ldren whose parents have prepared them for divorce will exh1bit a better developmental adjustment than chlldren not prepared for divorce.

3. The social economic circumstances of divorcing parents is inversely related to the development of cooperative parental styles.

4. The children of parents who have established a cooperative parental style will exhibit a better developmental adjustment than chlldren whose parents did not establish a cooperative parental style.

${ }^{45}$ Shirley Anne Paetzhold, "Pretesting a Questionna1re at the Solo Center on the Impact of Divorce on ChIldren and Parents" (unpublished practicum submitted to the Portland State University School of Soclal Work, in partial fulfillment of the requirements for the degree of Master of Social Work, 1975). 
Study Questions

The purpose of this study/is to determine if children exhibit negative behavior changes when experiencing their parents' divorce, and if so, what kind of changes occur, and what the severity of the changes is. $/$ In order to obtain this information, the IDCAP data were used. The IDCAP staff developed a questionnaire which was administered to their study sample. There were seventy questions which covered a variety of topics around the separation of divorce process. Certain predetermined questions were dealt with in more depth, and were called "probe" questions. Interviewers were instructed to ask for more information or explanation, encouraging the interviewee to respond more fully to the brief questionnaire statement. An attempt was made by the interviewers to maintain an attitude of "disciplined naivete" in order to allow spontaneous and subjective responses that were clearly the interviewee's own. Efforts were made not to lead or interfect comments. Probing questions such as, "Can you tell me a little more about.. . ?" were used.

Two questions concerned with the behavior changes in children provided the basis for our study. They are: "Have you noticed any change in your children's behavior since the divorce filing?" If the answer was yes, the interviewee was to check areas of change. Three areas were listed:
(a) health,
(b) school, and
(c) relationships.
These areas 
were broken down further, providing the interviewee with specific categories to check. "Health" was divided into eating, sleeping, complaints of feeling sick, fearfulness, and others. Both emotional and physical changes were included. "School" problems were composed of attendance, grades, and classroom behavior. Children's "relationships" problems were broken down into brothers and sisters, parents, neighbors, playmates, and friends, grandparents and other relatives.

These two questions our study examines were among the "probe" questions; therefore, more information about behavfor changes in children was recorded on. the tapes than on the questionnaires. Responses to our questions were manually recorded on Family Data Sheets. These sheets were made in order to record all data from each family that would be used in our study. We recorded first the family identification number, and sex of parent being interviewed. Each child's age; sex, and living arrangements were then noted. Social data, such as work status, and religious preference followed. Spaces were provided for noting any behavioral change and its severity.

Each parent's response was recorded separately on the Family Data Sheet. A total of seventy-four sheets was compiled, or thirty-seven families. After the data were collected, selected information was removed and Iisted on ind 1vidual sheets where frequency counts were made for each 
table. Different units were used in the tables such as family, the child, and the problem, depending on the 1ssue under investigation. Statistical analysis to determine statistical significance was used whenever relevant.

\section{Sample}

The study sample collection began June 12, 1975, and continued until December 31, 1975 (our cut-off date). Contact with families was made by Nolan Jones, IDCAP Assistant Research Director, who recelved the names of the divorcing couple and their attorneys' names from the Clackamas County Circult Court in Oregon City, Oregon. The sample was chosen randomly, beginning with the first petition flled after the beginning of the study time perlod and including every other petition filed. The person to be interviewed was sent a letter explaining the study and then contacted, and an appointment was set up for an interviewer to visit $\mathrm{h} 1 \mathrm{~m} / \mathrm{her}$. Each interviewed subject recelved $\$ 20.00$ for his participation. He was usually interviewed at home, first fllling out the questionnaire and then responding to the interviewer's questions.

Our sample included only IDCAP families where both parents had been interviewed. Our data were taken from two sources: the written questionnaires and the taped interview. If a tape was inaudible, the whole family was omitted from our study. 
A total of 126 couples had f1led for divorce, of which 113 had been drawn in the sample by our cut-off date of December 31, 1975. However, only one partner had been Interviewed in sixty-one cases, the other partner not having been reached or not yet interviewed, or in seven cases refusing to particlpate in the study for personal reasons. This left forty-five couples with both parties having been interviewed. There were five couples omitted because tapes were missing from the IDCAP flles, and three more were omitted because tapes were inaudible. This left a total of thirty-seven families we were able to include in our study sample.

The population studied by IDCAP was defined as first marrled divorcing couples with minor children living in Clackamas County, Oregon, flling for divorce after June 12, 1975.

Our thirty-seven familles have an income range of $\$ 400$ per month to $\$ 1,800$ per month, averaging (the mean) $\$ 1,066$ per month. The median income was $\$ 1,100$ per month. There were ninety-two children in these thirty-seven families with an average of 2.5 children per family. Their ages ranged from nine months to eighteen years, averaging 9.24 years. There were twenty-seven school age children (six years old and older), and sixty-five preschoolers, fortyseven boys and forty-five girls. 
Coding and Rellability

Rellability of coded data was determined through independent coding of parents' responses. First, the researchers listened to a number of tapes together, determinIng codes and discussing and scoring responses. Then each researcher proceeded to independently listen to the next ten tapes in the sample. The independent coding of the researchers was then compared. Based on this procedure, a rellabllity rate of 90 per cent was found; that is, we agreed 90 per cent of the time. Discussion of differences followed until consensus was reached. We then divided and listened to the remalnder of the sample independently. A number of times questions arose, were discussed, and an agreement was reached.

\section{Variables}

The first varlable to be coded was whether or not the child was percelved by the parent to have negatively changed. Often parents were in disagreement as to the existence and nature of the problem. If a parent considered a problem to exist, it was tabulated. The absence of a problem corresponds to a lack of an effect of divorce, while the degree of a problem corresponds to the effect of divorce on the child. A second variable was "severity." Behavior was rated "severe" if the parent reported that it occurred 
persistently and inhibited normal functioning. The "not severe" rating was given when parents reported problems that did not occur excessively and did not inhibit normal functioning. "No problem" signifies that there was no negative change in the child's behavior. Socio-economic variables used include family income, age and sex of child, religious preference, and work patterns of parents. These were not coded but were taken from the questionnaire.

\section{Iimitations of the Study}

The study examines parents' perceptions, thus we are not concerned with objective problems. Standardized methods of objectively determining and measuring problems was not used by the parents, and it is assumed they may have had reasons of their own for reporting or withholding data. It can be assumed also that parents were included in the study who did not percelve some problems in their children's behav1or. Therefore, the results obtained must be interpreted with caution, with the understanding that the results may be blased.

Because our population is very small, its generalizability to a larger population is questionable. It is better to have as large a sample as possible; however, our mandatory cut-off date dictated that our sample be limited. Since we have used a small sample, its application to other populations must be done carefully. We feel that results 
obtalned here may cautiously be used as a starting point for similar studies.

It has been noted that only thirty-seven of 113 couples who flled for divorce were included in our study. While elght couples were unable to be included because of technical errors, this still leaves sixty-eight couples in which one. spouse could not be reached to be interviewed, or refused to participate. This might eas1ly change the nature of our results somewhat, but since information was not gathered to examine these sixty-elght couples, we cannot say In what ways our results might be different.

The data gathering for this study was done over a six and one-half month period of time; however, much of the Interviewing was done during the summer months. Results become restrictive in that children were not in school and, therefore, did not very often provide a school setting in which to observe their behavior. Often the parents reported no change in school related behavior because the child was not in school during the time of his parents' separation. Had the interviews been done during the school months, results may have been somewhat different. 
CHAPTER IV

FINDINGS

There was a time when it was believed that those who divorce were "sick" people, hopeless neurotics who would repeat their fallure should they marry again. Today, the divorcing and divorced population is observed as coming from all walks of $11 f e$, with diversity of cultural backgrounds. The possibility that divorce will play a role in the lives of more adults and children is increasing. * Currently, three-fifths of divorces occur among couples with children. 46 Yet divorce is not universally approved or accepted in America, but is viewed as a solution for unbearable marttal conflict.

Are children affected by their parents' divorce? If they are, how are they affected? In the "Review of the Literature," we described several negative responses other researchers have discovered. However, children respond with a range of behaviors, some of which are not always negative. Positive reactions have been seen and reported by authors

${ }^{46}$ Esther 0. Fisher, "A Gulde to Divorce Counseling," The Family Coordinator, January, 1973, p. 55. 
such as Loulse Despert. 47 Our study does not include the positive reactions or improvements that some families in our sample may have seen.

The questionnaire from which we collected our data wasn't set up to discern between improvements or negative changes in behavior. We, as interviewers, used probing techniques when negative changes were indicated but did not pursue improvements. Since we did not obtain further information on positive changes, we are excluding observations of improvement, and are confined to studying the incidence of negative behavior changes in children. It is our intent to determine:

1. The existence of problems.

2. The types of problems found.

3. The severity of problems found.

4. Factors related to the child that make $\mathrm{h} 1 \mathrm{~m} / \mathrm{h} e \mathrm{r}$ likely to experience problems.

5. Factors related to socio-status of parents that make children likely to experience problems.

\section{Incidence of Problems}

Are children likely to show negative changes in behavLor when their parents divorce? If they do, how often do problems appear? Not all children exhibit problems. In fact, as Table I shows, a large number are seen to have no ${ }^{47}$ Despert, 1oc. cit. 
behavior change. On the other hand, parents reported that fifty-four out of ninety-two children sampled have a total of 120 problems.

\section{TABLE I}

INCIDENCE OF PROBLFM BEHAVIOR

AMONG CHILDREN

\begin{tabular}{ccc}
\hline Change & No Change & $\begin{array}{c}\text { Total } \\
\text { Children }\end{array}$ \\
\hline 54 & 38 & 92 \\
$59 \%$ & $41 \%$ & \\
\hline
\end{tabular}

The ninety-two children came from thirty-seven families. Of these, twenty-six reported problems, while eleven families did not.

TABLE II

INCIDENCE OF PERCEIVED PROBLEMS

IN FAMILIES

\begin{tabular}{ccc}
\hline Change & No Change & $\begin{array}{c}\text { Total } \\
\text { Families }\end{array}$ \\
\hline 26 & 11 & 37 \\
$70 \%$ & $30 \%$ & \\
\hline
\end{tabular}


We have seen that not all children respond to divorce by exhibiting negative behavior changes. But 59 per cent of the children in our sample did. Who are these children? Are there any characteristics which identify them? For instance, is it possible that sex is associated with behavior change? Our sample consisted of forty-seven boys and fortyfive girls. Table III suggests that parents percelve boys to have slightly more problems as a result of divorce than girls. However, this difference does not appear statistically significant.

\section{TABLE III}

SEX OF CHILD AND PERCEIVED

BEHAVIOR CHANGE

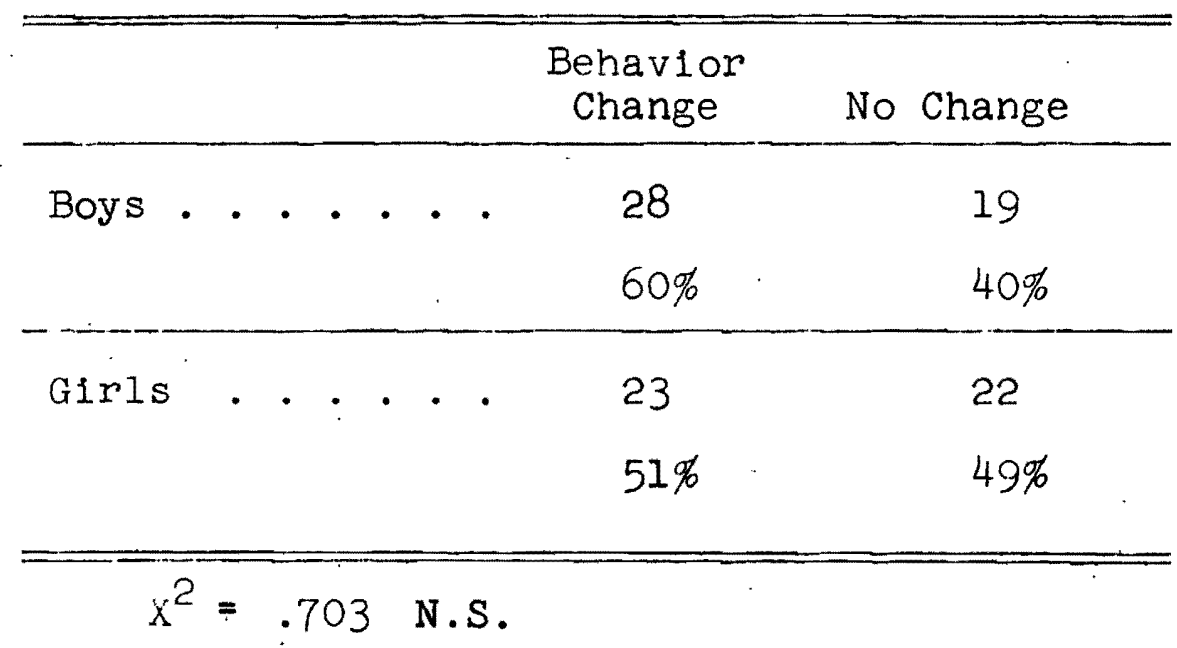

Does the age of the child affect perceptions of negative behavior change? We have divided the children into three age groups. There are a total of twenty-seven preschoolers, twenty-nine grade school children, and thirtysix junior high and high school students. 
TABLF. IV

AGE OF CHILD AND PERCEIVED

BEHAVIOR CHANGE

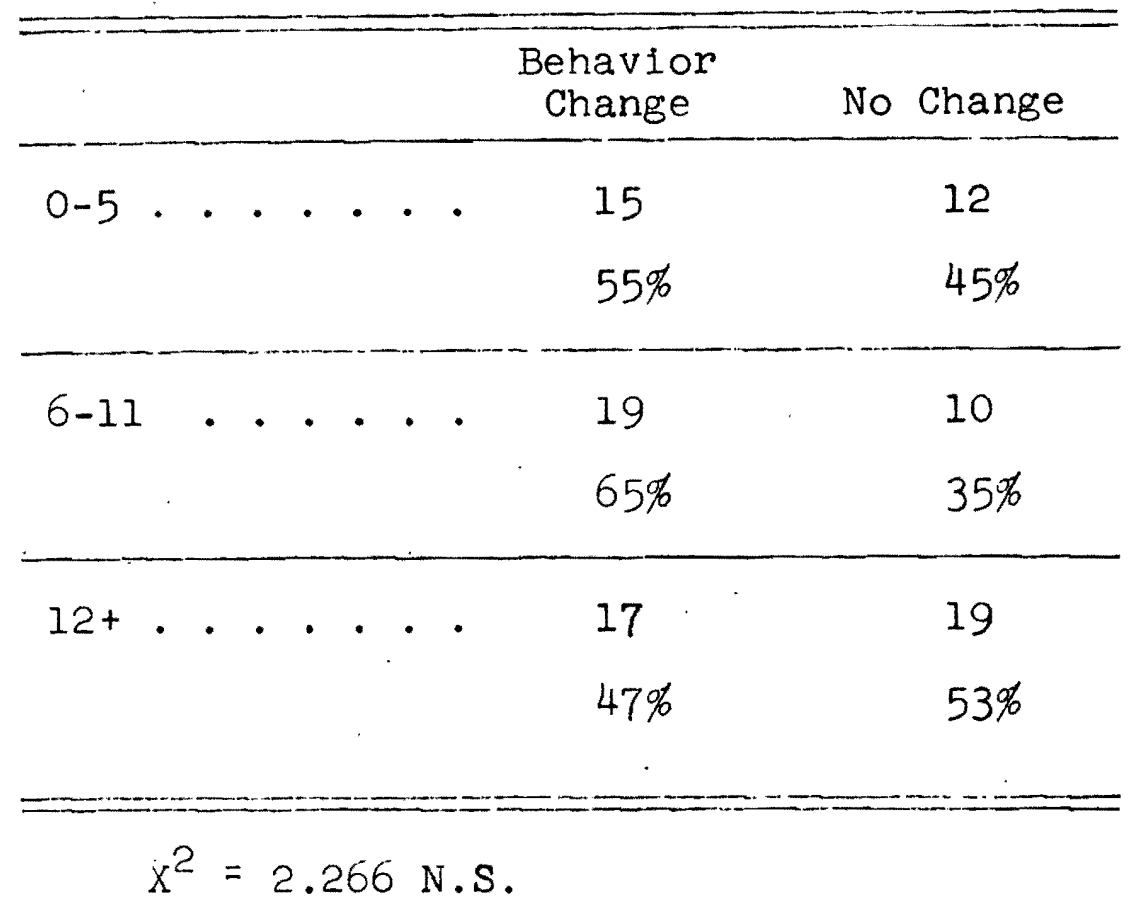

In general, parents perceive problems among all age categories. However, children under twelve are percelved to have proportionately more problems than children twelve or older. Among children twelve or older, the likelihood is about equal that they w111 be percelved to have problems as a result of divorce. However, again the differences don't appear statistically significant.

Families differ in socio-economic and religious factors. Is it posșible that income affects the incidence of problems or that problems are more likely to occur in 
certain economic levels? The measure of economic status used here is annual family income. The division of wage levels into three groups was made after consulting the Statistical Abstract of the U.S., 1974. These groupings are belleved to represent distinctive economic levels, although the limits are somewhat arbitrary.

\section{TABLE V}

ECONOMIC STATUS AND PERCEIVED NEGATIVE BEHAVIOR CHANGE OF CHILDREN

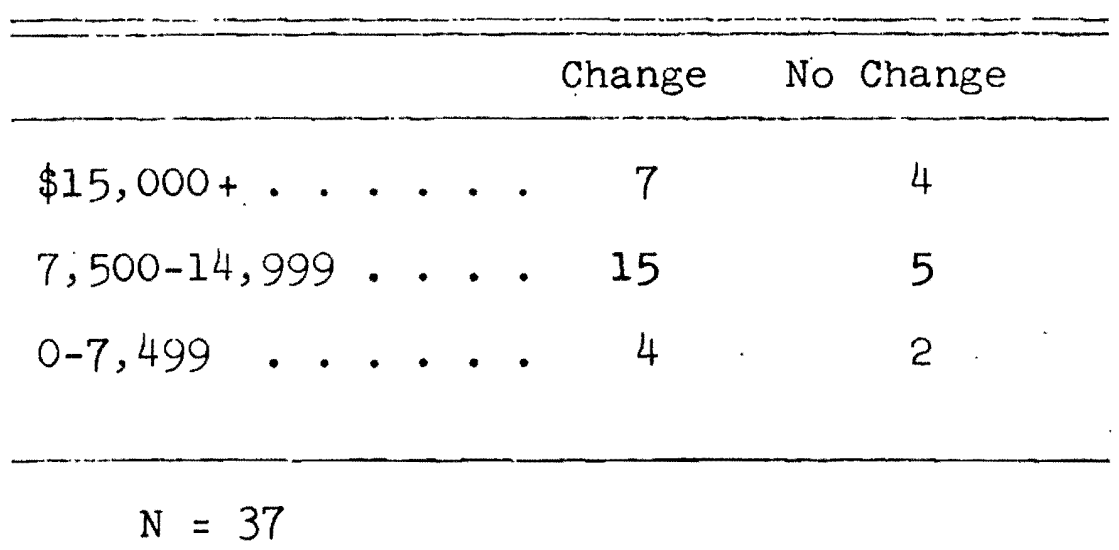

There appears to be little difference according to family income. At all income levels, parents are likely to percelve problem behavior in children.

Another characteristic that differs from family to family is religious preference. Is it possible that the perception of problems among children will be affected by the religion of the parents? If one parent indicated no preference, religious preference of the other parent was used. In one case, a person indicated "Jewish," but because 
his spouse marked "Catholic," the family was considered "mixed." Other mixed families included one Catholic or Protestant, and one parent who claimed no preference.

TABLF. VI

RELIGIOUS PREFERENCE AND PERCFIVED

NEGATIVE BEHAVIOR CHANGE

OF CHILDREN

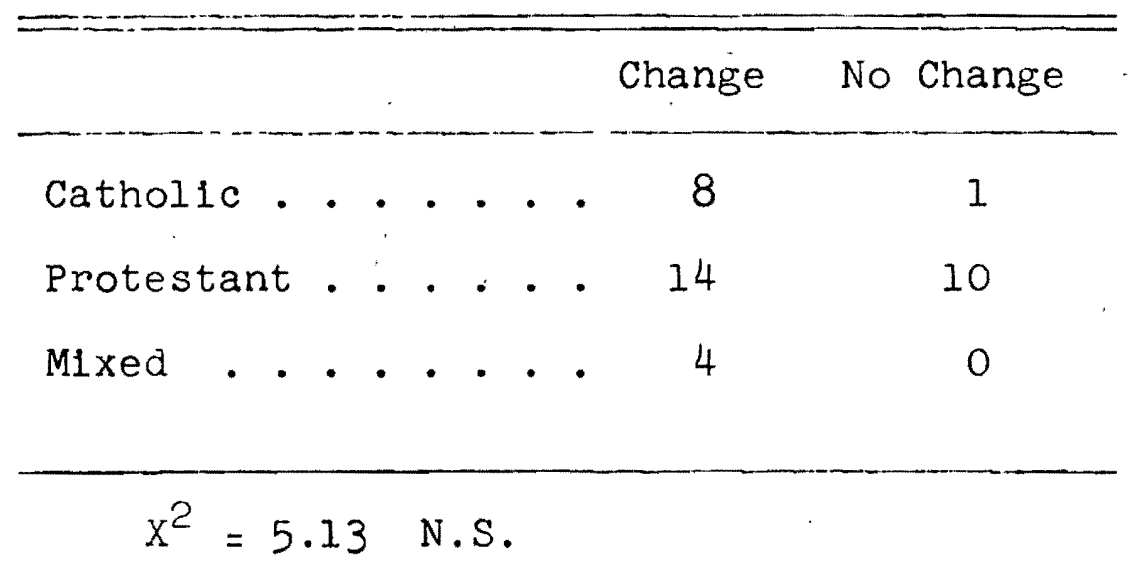

The religion of parents does not appear to affect their perception of problems among children. Although there is a tendency for Catholic and mixed parents to report problems proportionately, this is not statistically significant. In traditional American families, the mother remains at home to care for the children. Are traditional families who break up, more likely to generate problems for children? or, said differently, does having arranged the family in. other than traditional terms, such as where both parents work, produce more problems for children as a result of divorce? 
TABLE VII

AMOUNT OF TIME BOTH PARENTS SPEND WORKING

AND PERCEIVED INCIDFNCE

OF PROBLFIMS

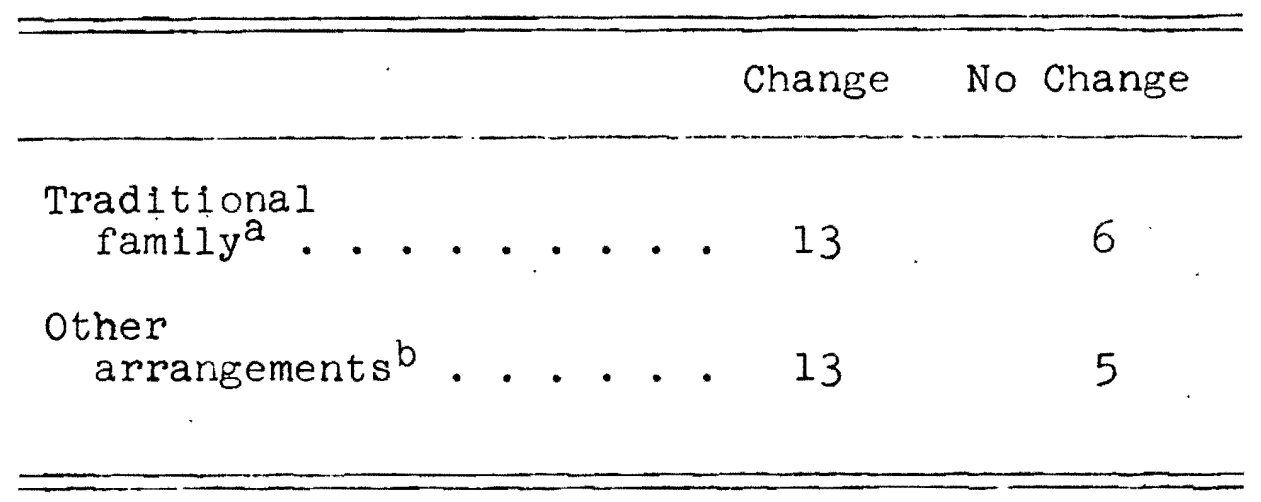
home.

$a_{\text {Traditional family }}=$ father working, mother

$\mathrm{b}_{\mathrm{All}}$ other arrangements, including families in which both parents work, where one works full time and one part time, or neither works.

Table VII suggests no difference in reported problem behavior of children as a result of having diverged from traditional patterns.

Are the effects of divorce more likely to be demonstrated by one child in a family rather than by all the children. When one person is victimized to the benefit of others, the term "scapegoating" is often applied. 48 Table VIII rates children according to percentage of probiems reported for all children in families with three or more ${ }^{48}$ Vogel and Bell, 10c. c1t. 
children in an effort to determine whether one child might be displaying most of the problems.

TABLE VIII

PROBLEMS OF CHILDREN IN FAMILIES

OF THREE OR MORE CHILDREN

\begin{tabular}{|c|c|c|c|c|c|c|}
\hline Family No. & $\begin{array}{c}\text { Child } \\
\text { No. I } \\
(\dot{y})\end{array}$ & $\begin{array}{l}\text { Child } \\
\text { No } 2 \\
(\dot{\phi})\end{array}$ & $\begin{array}{c}\text { Child } \\
\text { No } 3 \\
(\dot{\phi})^{3}\end{array}$ & $\begin{array}{c}\text { Child } \\
\text { No } 4 \\
(\%){ }^{4}\end{array}$ &  & $\begin{array}{c}\text { Child } \\
\text { No. } 6 \\
(\not{\phi})\end{array}$ \\
\hline 1 & 0 & 25 & 75 & - . & . $\cdot$ & - . \\
\hline 2 & 57 & 43 & 0 & . . & . . & . . \\
\hline 3 & 100 & 0 & 0 & . . & . . & . . \\
\hline 4 & 0 & 0 & 0 & 0 & . . & . $\cdot$ \\
\hline 5 & 0 & 50 & 50 & - . & . . & - . \\
\hline 6 & 100 & 0 & 0 & - . & - . & . . \\
\hline 7 & 0 & 0 & 0 & 0 & 0 & . . \\
\hline 8 & 17 & 17 & 17 & 17 & 17 & 17 \\
\hline 9 & 33 & 33 & 33 & $\cdot \cdot$ & - $\cdot$ & $\cdot \cdot$ \\
\hline 10 & 12 & 25 & 38 & 25 & . . & . . \\
\hline 11 & 0 & 0 & 0 & 100 & . . & . . \\
\hline 12 & 0 & 25 & 0 & 50 & 25 & - $\cdot$ \\
\hline 13 & 66 & 17 & 17 & - . & . $\cdot$ & - $\cdot$ \\
\hline 14 & 63 & 37 & 0 & - . & . . & . . \\
\hline
\end{tabular}

In three families of three or more chlldren, one child is perceived to be experiencing all the problems. In 
two other families one child seems to be bearing the brunt of problems. These cases may indicate scapegoating. In no other instances, however, does scapegoating appear to be occurring.

Types of Problems.

The words "problem" and "negative behavior change" have been used interchangeably in this chapter.

What kinds of problems do parents perceive in their children as a result of divorce? Our findings support the literature concerning changes in children after divorce. 49 While some exhibit no behavioral changes, others seem to make improvements. Many, however, react to the event in ways which may be consldered negative. Some of the negative changes reported in the literature and also found here are hostility towards parents and siblings, acting-out behavior, fearfulness, withdrawing, feelings of depression and grief.

For the fifty-four chlldren in our study percelved to have problems, the negative behavior changes most frequently cited by parents were health, school and Interpersonal problems. Health problems were clted most often. Table IX shows the distribution of problems in these three categories.

${ }^{49}$ Land1s, Ioc. c1t.; Despert, 10c. c1t.; J. Bowlby, "Processes of" Mourning," International Journal of Psychoanalysis, Vol. 42, 317-340, 1961; and M. Sugar, "Children of Divorce," Pediatrics, 46, 588-95, 1970. 
TABLE IX

INCTDENCE OF PROBLEMS IN HEALTH, INTERPERSONAL AND SCHOOL

CATEGORIES

\begin{tabular}{cccc}
\hline Health & $\begin{array}{c}\text { Inter- } \\
\text { personal }\end{array}$ & School & $\begin{array}{c}\text { Total No. of } \\
\text { Reported } \\
\text { Problems }\end{array}$ \\
\hline 59 & 49 & 12 & 120 \\
\hline
\end{tabular}

1. Health problems include both physical and emotional changes. Among the physical problems reported were: eating difficulties, disturbed sleep, nausea, vomiting, increase in urinary frequency, complaints of feeling 111 . The emotional changes included grief, sadness, crying, regressive behavior, and fearfulness. Of the 120 problems reported, fifty-nine are in the health category.

TABLE $X$

INCIDENCE OF HEALTH PROBLEMS

\begin{tabular}{lcccc}
\hline Eating & Sleeping & $\begin{array}{c}\text { Complaints } \\
\text { of Feeling } \\
\text { Sick }\end{array}$ & $\begin{array}{c}\text { Fearful- } \\
\text { ness }\end{array}$ & Other \\
\hline 5 & 13 & 23 & 14 \\
\hline
\end{tabular}


The category of "other" includes silence and withdrawing behavior. Parents most frequently reported that their children were afraid of things that had previously not bothered them; most often, it was that the remaining parent might leave.

2. * School problems include such changes as lowered interest or achievement in school work, hostillty toward teacher, Increased absence from school, or increased problem behavior in the classroom. Table XI represents only those children in school. Forty-seven children are over six years of age, although there are a few who attend nursery school.

TABLE XI

、 INCIDFNCE OF SCHOOL PROBLEMS

\begin{tabular}{ccc} 
Attendance & Grades & $\begin{array}{l}\text { Classroom } \\
\text { Behavior }\end{array}$ \\
\hline 1 & 3 & 8 \\
\hline
\end{tabular}

In no case was this behavior considered to be excessive by the parents. Most of the problems were acting out in the classroom.

3. The interpersonal problems cited by parents were: (a) problems with parents, including runaways; (b) problems with siblings; (c) problems with peers; and (d) problems 
with others. These problems were generally demonstrated by deflance, hostility, acting-out behavior toward an ind1vidual, or withdrawal from another person. Of the 120 problems, fifty were concerned with the child's interpersonal relationships.

TABLF. XII

INCIDENCE OF INTERPERSONAT, PROBL FMS

\begin{tabular}{cccc}
\hline Parents & Siblings & Peers & Others \\
\hline 33 & 10 & 2 & 4 \\
\hline
\end{tabular}

Relationship problems with parents received an overwhelming majority. It is possible that parents would perceive problems in their relationships with the child and not be as aware of problems in other relationships, which could account for this concentration. They may also be more aware of relationship problems within the home, as with siblings, than those occurring outside the home.

Severity

We have found that negative behavior change is reported for fifty-four children out of the ninety-two. Just how severe are the problems reported? The problems were rated in terms of their severity. Those categorized as "not 
severe" include behavior change not occurring excessively or not inhibiting normal functioning. A "severe" problem is defined as a change in behavior that occurs persistently and inhibits normal functioning.

TABLE XIII

INCIDENCE OF PERCEIVED SEVERE

AND NOT SEVERE PROBLEMS

\begin{tabular}{ccc}
\hline Severe & Not Severe & No Problems \\
\hline 17 & 109 & 115 \\
\hline
\end{tabular}

$N=241$

Severity of Problems for Individual Children. This measure of severity will rate not individual problems, but the total problems reported for a certain child; that is, the degree to which a child exhibits behavior change. If one-fifth, or 20 per cent of the problems for a particular child had been rated "severe," we then rated him/her as experiencing severe problems. When fewer than that number had been rated "severe," or other problems were perceived, we considered the child's rating as "not severe." If "no change" was reported, he was rated as having no problems. 
TABLE XIV

INCIDENCE OF SEVERITY RATINGS OF CHILDREN AS PERCEIVED BY PARENTS

\begin{tabular}{cccc}
\hline \hline Severe & Not Severe & $\begin{array}{c}\text { No } \\
\text { Problems }\end{array}$ & $\begin{array}{c}\text { Total } \\
\text { Ch1ldren }\end{array}$ \\
\hline 9 & 45 & 38 & 92 \\
$10 \%$ & $49 \%$ & $41 \%$ & \\
\hline
\end{tabular}

Does the sex of the child correlate with the severity of perceived behavior change? In Table III we found that there was no significant difference between the sex of the child and percelved problems. Here we add severity rating to the Incldence of problems to determine whether one sex is percelved by parents to have more severe problems.

\section{TABLE XV}

SEX OF CHILD AND PERCEIVED SEVERITY OF BEHAVIORAL CHANGE

\begin{tabular}{cccc}
\hline & Severe & Not Severe & None \\
\hline Boys.$\cdots$ & 5 & 23 & 19 \\
& $11 \%$ & $49 \%$ & $40 \%$ \\
\hline Girls.$\cdots$ & 4 & 19 & 22 \\
& $9 \%$ & $42 \%$ & $49 \%$ \\
\hline
\end{tabular}


There is little difference in frequencies of percelved problems of boys and girls. Parents percelve them to experlence the same severity of problems.

Does the age of the child correlate with the severity of perceived behavior change? In Table IV we found that there was no significant difference between the age of the child and perceived problems. We now add severity ratings to incidence of problems to determine whether one age group has more severe problems. Although the number of children perceived to be experiencing problems is so small, there does not appear to be any significant relationship between age and severity.

TABLE XVI

AGE OF CHILD AND PERCEIVED SEVERITY

OF BEHAVIORAL CHANGE

\begin{tabular}{|c|c|c|c|c|}
\hline Age & Severe & Not & Severe & No Change \\
\hline $0-5$ & $\begin{array}{l}2 \\
7 \%\end{array}$ & & $\begin{array}{l}13 \\
48 \%\end{array}$ & $\begin{array}{l}12 \\
45 \%\end{array}$ \\
\hline $6-11$ & $17 \%$ & & $\begin{array}{l}14 \\
48 \%\end{array}$ & $\begin{array}{l}10 \\
35 \%\end{array}$ \\
\hline $12+$ & $\begin{array}{l}2 \\
5 \%\end{array}$ & & $\begin{array}{l}15 \\
42 \%\end{array}$ & $\begin{array}{l}19 \\
53 \%\end{array}$ \\
\hline
\end{tabular}

$$
N=92
$$


Severity of Problems Within Families. This measure of severity will rate not individual problems, or the degree to which a child exhilits behavior change, but the degree to which a family exhibits behavior change. We combined the total percelved problems in a family. If one-fifth, or 20 per cent of the problems had been rated "severe," we then rated the family as experiencing severe disruption. When less than that amount had been rated "severe," or other problems were percelved, the family was rated as "not severe." If "no change" was reported for any child, the family was considered as having no problems.

TABLE XVII

INCIDENCE OF PERCEIVED SEVERITY

IN FAMILIES

\begin{tabular}{cccc}
\hline \hline Severe & Not Severe & No Change & $\begin{array}{c}\text { Total } \\
\text { Familles }\end{array}$ \\
\hline 5 & 21 & 11 & 37 \\
$13 \%$ & $57 \%$ & $30 \%$ & \\
\hline & & & \\
\hline
\end{tabular}

A majority of children showed problems, but only nine out of ninety-two showed severe behavioral change, or seventeen of 241 problems were rated as "severe." Because only five families suggest severe disruption has occurred, we 
don't have a sufficient number of cases to properly analyze such data further.

Although there were 120 problems reported for fiftyfour chlldren, very few parents reported the same problem for their child. In thirty-eight cases, both parents agreed the child had no problem, but there were only four children whose parents both agreed on the problem that child had. Some of the reasons for this might be that: (1) the parent is bitter and reports more problems; (2) the parent is sensitive to criticism and doesn't want to be seen as incapable; or (3) the child may expose his/her problems to only one parent. Certalnly, the lack of communication between parents is evident.

Summary

In this chapter we have reported the incidence of behavior changes in children as percelved by their parents. We found, first, that a majority of children are perceived to experience problems as a result of divorce. Secondly, these problems happen at random. They appear unrelated to the age or sex of the child, and the income or religion of the parents. Thirdly, although a majority show problems, only a small percentage show severe problems. Once again, the age or sex of the child, and the income or religion of parents, appear unrelated to the severity of problems. 
* The kinds of problems likely to be percelved by parents are health, school and interpersonal. Health problems appear to be most common with interpersonal problems next in importance. 


\section{CHAPTER V}

\section{CONCLUSIONS}

\section{Discussion}

Not all children whose parents are divorcing experlence negative behavior problems. The study did not explore the possibility that divorce might actually be a positive experience for some children. Nevertheless, the parents interviewed in this study reported that a majority of their children did experience problems.

Our findings indicate that a majority of children are percelved by their parents to have problems as a result of divorce. These problems include health problems, interpersonal problems, and school related problems. There are very few children who show severe changes. Further, the age or sex of the child appears unrelated to the incidence of problems. Similarly, the religious preference or income level of a family, also, appears not to be significantly correlated to the incidence of parents' perceptions of problems in children. Finally, parents rarely agree in their perceptions of problems in their children. While this may in fact be indicative that the child Is experiencing problems, it may also be related to the parents' feelings about the divorce. There appears to be an 
overwhelming breakdown in communication between parents. This is exhibited in the differing perceptions by the parents of their children's problems, which was most evident when the same interviewer talked to both the husband and wife. They appeared not to be reporting their concerns to each other, or coming to an agreement about which problems a child had.

Our own observations as interviewers also leads to this conclusion. Some parents, as a result of divorce, encountered a "period of confusion" or a general disorganization which was experienced by the whole family. For instance, one parent stated, "Everyone was really upset for about a week, then things began to settle down."

* When a couple separates, it is often traumatic for one or both parents. It is possible that they become so involved in their own problems that it is hard for them to recognize their children's needs. It was during this period that the parents were interviewed. We did observe that they wanted to talk about their spouses quite often. It is perhaps the parents rather than the children who are in more trauma and in greater need of help when the divorce occurs. Often it was noted by the parents that relationship patterns changed. For example, the noncustodial parent sometimes related to the children better than when he resided in the home. He would often begin to "spoll" them. Several fathers reported spending more time with their 
children and enjoying them more. However, in other situations, noncustodial parents "dropped out of the picture," seldom being heard from. * Some reported that they stayed away from their children because of the pain associated with seeing them. Occasionally children were noticed to exhibit clinging behavior towards their noncustodial parent, fearing he/she would not return.

Although a child would sometimes show anger towards a parent, others began helping and even comforting him/her. Some children grew closer to their parents after the tension of the stressful marriage had ceased. Fighting among children was percelved to be less by many parents, and one sald her "children were getting along better." other parents reported their children were communicating more with each other, and becoming closer.

It is probably true that both parents and children suffer during the divorce process so that we cannot completely ignore the perceptions of parents. Many parents reported negative behavior changes which are consistent with the literature on this subject. It is likely that children do react in varlous ways to the divorce process.

There may be a number of variables that may be influential in determining when problems will occur which were not used in this study. For instance, educational level of parents, or quality of time parents spend with their children, as well as the kind of relationship and parenting 
styles that persisted before the divorce occurred could affect children's reactions to divorce. However, the varlables we have used in this study do not predict incidence and severity of problems perceived in children.

Implications for Soc1al Work

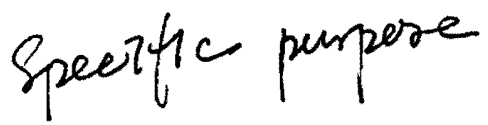

Historically, social work has been more involved in family counseling than other helping professions. Therefore, it is important that, as a profession, we are aware of recent trends in divorce and the impact of divorce on family members. We need to be aware, also, of the possible negative effects on the children of a family who is going through the separation and divorce process.

By being prepared to deal with the problems sometimes caused by divorce, the soclal worker could help the family through a possibly stressful situation. To be more effective, the worker must te as open-minded as possible. To be most effective, we need to recognize the potential for problems, and then to discover which problems occur most often. The next step is learning how to work with families to alleviate or reduce such problems. Another approach is to work toward prevention of problems, by writing or teaching parenting and communication skilis.

Although divorce is not always harmful to children, as this study has shown, often there are problems. When parents are involved in the problems divorce causes for them, 
they may not be able to respond in a helpful way to their children's problems. It is here that our services would be very useful. The soclal worker can assist the parents in coping with their own conflicts, which will indirectly help them care for their children.

The general goal of divorce counseling is for spouses to gain insight into and understanding of their personal and marital conflicts and difficulties, together with enough emotional strength to make decisions and deal more adequately and responsibly with the problems caused by divorce.

\section{Recommendations for Future Research}

While working on this project, we have continually been interested in the positive behavior changes children sometimes demonstrate. We found that it does occur with some frequency, but positive aspects of divorce have not been documented to our knowledge.

There is a need to have future research directed to focusing on both positive and negative behavior changes in children, an integration of the two presented in one study. It would be valuable for one study to look at both positive and negative changes taken from the same sample population. There is also a great need for research directed toward long-term evaluation of behavior changes in children. 


\section{BIBLIOGRAPHY}

Anthony, E. James and Cyrille Koupernile, eds. 1970. The Child in His Famlly. New York: John Wiley \& Sons, Inc.

Benedict, Ruth 1959. "The Family: Genus Americanum," The Family: Its Function and Destiny. Edited by Ruth N. Anshen New York: Harper \& Bros.

Bergler, Edmund 1948. "Dlvorce Won't Help. New York: Harper \& Row.

Bernard, Jessie 1972. The Future of Marriage. New York: World Publishing.

Bernstein, Norman R. and J. S. Robey 1962. "The Detection and Management of Pediatric Difficulties Created by Divorce," Pediatrics, 30, 950-6.

Blumenthal, Monica D. 1967. "Mental Health Among the Divorced," Archives of General Psychiatry, Vol. 16, 603-8.

Bohanan, Paul, ed. 1970. Divorce and After. Garden City, New Jersey: Doubleday \& Company, Inc.

J. Bowlby 1951. Maternal Care and Mental Health. Geneva, World Health Organization.

1961. "Processes of Mourning," International Journal of Psychoanalysis, Vol. 42, 317-40.

Browning, Charles J. 1960. "Differential Impact of Family Disorganization Upon Male Adolescents," Social Problems, Vo1. 8, Summer.

Burchinal. Lee 1964. "Characteristics of Adolescents from Unbroken Homes and Reconstituted Families, "Journal of Marriage and Family, 26, 44-51.

Burgess, Jane 1970. "The Single-Parent Famlly: A Social and Psychological Problem," The Family Coordinator, XVIX, 2 . 
Croog, Sydney H. 1970. "The Family as a Source of Stress," Social Stress. Edited by Sol Levine and Norman A. Scotch. Chlcago: Aldine.

Davis, Kingsley 1948. Human Society. London: Macmillan.

Despert, J. Loulse 1962. Children of Divorce. Garden City, New York: Dolphin.

Douglas, J. W. B. 1970. "Broken Families and Child Behavlor," J.R. Coll. Physicians, London, 4, 203-10.

Esman, Aaron H. 1964. "Medical Aspects of Human Sexuality," Marriage and Family, 26, 44-51.

Fisher, Esther 0. 1973. "A Guide to Divorce Counseling," The Family Coordinator, January, 55-61.

Gardner, Richard A. 1970. The Boys and Girls Book About Divorce. New York: Bantam Books.

1974. "Psychological Aspects of Divorce," American Handbook of Psychlatry. Edited by Silvano Arleti. New York: Basic Books.

Gettleman, Susan and Janet Markowitz 1974. The Courage To Divorce. New York: Simon and Shuster.

Glasser, Paul H. and Lois N. Glasser, eds., 1970. Families in Crisis. New York/London: Harper \& Row.

Glueck, S. and E. Glueck 1950. Unraveling Juvenlle Delinquency. Cambridge: Harvard University Press.

Golenpaul, Dan, ed.; 1974. Information Please Almanac. New York: Macmilian.

Goode, W1lliam J. 1956. After D1vorce. Glencoe, Ill.: The Free Press.

1956. Women in Divorce. Glencoe, Ill.: The Free Press.

1964. The Famtly. Englewood Cliffs, New. Jersey: Prentice Hall.

Grollman, Earl A., ed., 1969. Explaining Divorce to Children. Boston: Beacon Press. 
Hardy, Richard E. and John G. Cull 1974. Creative Divorce Through Social and Psychological Approaches. Springfield, Ill.: Charles C. Thomas.

Harris, C. C. 1967. The Family: An Introduction. New York: Praeger Publishers.

Jou rard, Sidney M. 1972. The Transparent Self. New York: D. Van Nostrand Company.

Kessler, Jane W. 1966. Psychopathology of Childhood. New Jersey: Prentice Hall, Inc.

Laing, R. D. 1973. "The Mystification of Experience." Radical Psychology. Edited by Phil Brown. New York: Harper \& Row.

Landis; Judson T. 1960. "The Trauma of Children When Parents Divorce," Marriage and Family Living, 22, 7-13.

1963. "Social Correlates of Divorce or Nondivorce Among the Unhappy Married," Marriage and Family Living, May, 178-9.

Leslie, Gerald R. 1967. The Family in Soclal Context. New York: Oxford University Press.

Lichtenburger, James P. 1968. Divorce: A Study in Social Causation. New York: AMS Press.

Linton, Ralph 1959. "The Natural History of the Family." The Family: Its Function and Destiny. Edited by Ruth N. Anshen. New York: Harper \& Bros.

Littner, Ner 1973. "The Effects on a Child of Family Disruption and Separation From One or Both Parents." Paper presented to 1lth Annual Conference of Conciliation Courts, Chicago, Ill., May 19.

Lopata, Helena 7.., ed., 1973. Marriages and Families. New York: D. Van Nostrand Company.

Mahler, M. S. and R. Rabinovitch 1956. "A Re-evaluation of Marital Conflict on Child Development." Neurotic Interaction in Marriage. Edited by $v$ w. Eisenstein. New York: Basic Books.

McDermott, J. F. 1968. "Parental Divorce in Early Childhood," American Journal of Psychiatry, 124, 1424-32. 
McDermott, J. F. 1970. "Divorce and Its Psychiatric Sequalae in Children," Archives of General Psychiatry, $23,421-7$.

Merton, Robert K. 1949. "The Self-Fulfilling Prophecy," Soclal Theory and Soclal Structure. Glencoe, Ill.: The Free Press.

Morrison, J. R. 1974. "Parental D1vorce as a Factor in Childhood Psychiatric Illness," Comprehensive Psychiatry, 15(2), 95-102.

Mortlock, Bill 1972. The Inside of Divorce. London: Constable.

Nye, F. Ivan 1957. "Child Adjustment in Broken and in Unhappy Unbroken Homes," Marriage and Family Living, $19,356-61$.

Ogburn, W. F. and M. F. Nimkoff 1955. Technology and the Changing Family. Boston: Houghton Miffilin Company.

O'Ne11, Nena and George O'Ne11 1972. Open Marriage. New York: Avon Books.

Otterstrom, Edith 1952. "The Soclal Outlook for Children of Divorce," Acta Genetica et Statistica Medica, Vol. 3, 72-96.

Paetzhold, Shirley Anne 1975. "Pretesting a Questionnaire at the Solo Center on the Impact of Divorce on Ch11dren and Parents." Unpublished practicum, Portland State University School of Social Work.

Parsons, Talcott 1959. "The Soclal Structure of the Family." The Family: Its Function and Destiny. Edited by Ruth N. Anshen. New York: Harper \& Bros.

Plateris, A. A. 1970. "Divorce Statistics Analysis: United States--1963," Public Health Service Publication No. 1000 , Series 21, No. 13. Washington, D.C.: Government Printing office.

Pollak, Otto 1964. "The Broken Family." Soclal Work and Social Problems. Edited by Nathan E. Cohen, National Assoclation of Social Workers, Inc.

Redl, Fritz and David WIneman 1951. Chlldren Who Hate. New York: The Free Press of Glencoe. 
Rheinstein, Max 1972. Marriage Stablilty, Divorce and the Law. Chicago: The University of Chicago Press.

Sherwin, Robert V. 1969. Compatible Divorce. New York: Crown Publishers, Inc

Singleton, Mary Ann 1974. Life After Marriage. New York: Stein and Day.

Snow, John H. 1971. On P1lgrimage: Marriage in the 70's. New York: The Seabury Press.

Spitz, R. 1954. "Unhappy and Fatal Outcomes of Emotional Deprivation and Stress in Infancy." Beyond The Germ Theory. Edited by I. Goldston. New York: Academy of Sciences, Health Education Council.

Steinzor, Bernard 1969. When Parents Divorce. New York: Pocket Books.

Stuart, Irving R. and E. Abt Lawrence 1972. Children of Separation and Divorce. New York: Grossman PubI1shers.

Sugar, M. 1970. "Children of Divorce," Pediatrics, 46, 58895.

Udry, J. R. 1971. The Social Context of Marriage, 2nd ed. New York: J. B. Lippincott.

Vogel, E. F. and N. W. Bell 1960. "The Emotionally Disturbed Child as the Family Scapegoat." The Family. Edited by N. W. Bell and E. F. Vogel. New York: Free Press.

Westman, Jack D. 1965. "The Effect of Divorce on a Child's Personality Development," Mental Health Digest, 4, 248.

Westman, J., et al., 1971. "The Role of Ch1ld Psychlatry In Divorce," Archives of General Psychiatry, 23, 41618.

Whitaker, C. A. and M. H. Miller 1969. "A Re-evaluation of Psychiatric Help When Divorce Impends," American Journal of Psychiatry, 126, 611-18.

U.S. Department of Commerce, Bureau of the Census 1975. Statistical Abstract of the United States. Washington, D.C.: Government Printing office. 
U.S. Department of Health, Education and Welfare, Public Health Service 1975. Vital Statistics of the United States, Vol. 3. Washington, D.C.: Government Printing office. 
APPENDIX I 


\section{IMPACT OF DIVORCE ON CHILDREN \\ AND THEIR PARENTS}

QUESTIONNAIRE 
1. How many chlldren do you have?

Age Sex. Grade level School Name

2. Please check the f'ollowing to indicate those people NoW living with you:

___ No one, Children, ___ Mother and/or Father,

Mother-in-law and/or father-in-law, _ Other rela-
tives, _ Housekeeper, __ Friends, __ Other
describe)

3. Religlous preference:

Protestant, __ Catholic, _ _ Jew1sh, _ _ Other,
None

4. Did you have a religlous ceremony at the time of your marriage?

Yes No

5. Do you attend church or synagogue?

Yes No 
6. If yes to \#5, how often do you attend?

— Dally _ Weekly Once a month

- Few times a year

7. Do any of your children attend Saturday or Sunday School? Yes No

8. If yes to \#7, how of ten do they attend?

_Daily Weekly_once a month

_ Few times a year

9. What part did your religious belief play in you and your spouse's decision to file for divorce?

Not important __ Somewhat important

Very important

10. Race/ethnic 1dentification:

__ Caucasian, __ Black (Negro), ___ Chicano (Mex1can American), Oriental, Native $\Delta$ merican (American Indian)

D11. Are yoù currently working? __ Yes, __. No 012. If yes to \#11, are you working __ Full time, Part time, __ Other (describe)

13. What is your occupation? 
14. How long have you been working at present job?

1 month or less, 1-6 months, 7-11 months, $1-2$ years, More than 2 years

15. What is your monthly income before anything is taken

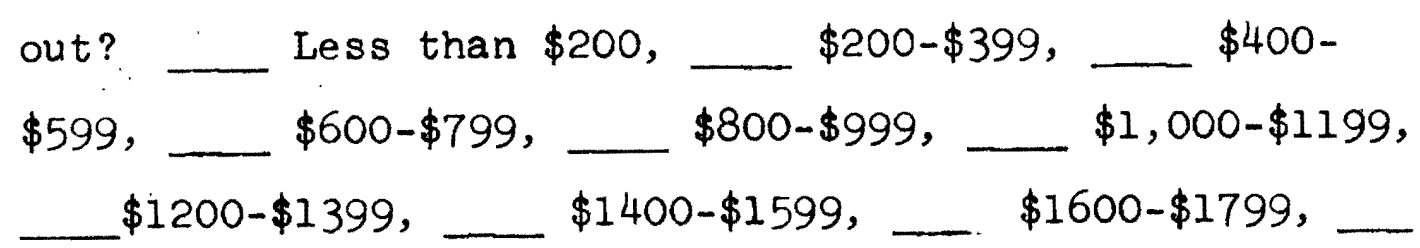
$\$ 1800 \&$ up

16. If you are not working, how long have you been out of work? Less than 1 month, Between 1-6 months, Never worked

17. Are you a student or involved in a work training program? _. Yes, No

18. If yes to \#17, are you involved Full time, Part time

19. If no to \#17, do you plan to seek more schooling or other training? __ yes, __ No

20. What was you work history before marriage? __ Never worked, __ Worked full time, __ Worked part time

21. What has been your work history during marriage?

Never worked, Worked full time, Worked part time 
22. How many jobs have you held during the past flve years? _ None, __ $1, \ldots 2, \ldots 3$ __ 4 or more

$\Delta 23$. If you are working, who takes care of your chlldren on a regular basis? other parent, Relatives,

Child care center, Baby sitter, Take care of themselves, other (explain)

24. How many times have you and/or your spouse filed for divorce?

This is the first time, _ 2 times, __ 3 or more
times

25. Had you ever considered separating before deciding to flie for this divorce?

Y Yes, No

26. If yes to \#25, how long had you considered a separation before fliling for divorce?

__ Less than a week, ___ 1-3 weeks, 1-3 months,

_ 4-6 months, _ over 6 months, _ 1 year \& over

27. Are you and your spouse now living apart? __ Yes, No

28. If yes to \#27, for how long? Less than a week, 1-3 weeks, _ 1-3 months, _ 4-6 months, over 6 months, _ 1 year \& over 
29. Have you ever talked to anyone about those problems leading to you and your spouse filing for divorce? Yes, No

30. If yes to \#29, please check with whom you have talked about these problems.

Relatives, - Clergyman, $\quad$ Family doctor,
Attorney, _ Psychiatrist, - Psychologist,
Marriage \& family counselor, _ Social worker,
Other (describe)

31. Are you now recelving professional counseling about those problems leading to you and your spouse fliling for divorce?

$\ldots$ Yes, _ N N

32. If yes to 31 , please check to whom you have talked about these matters.

Family doctor, __ Psychiatrist, ___ Psycholo-
gist, _ Marriage \& family counselor, __ Social
Worker, _ Clergyman, _ Other

33. Describe briefly some of the reasons you or your spouse declded to flle for divorce.

34. Do you want the divorce? __ Yes, __ No

3.5. Has the divorce been discussed with your children? Yes, № 
36. W1th whom w1ll the children be living if you and your spouse separate or divorce?

$\therefore \mathrm{Me}$

Spouse,

Other, Has not been

decided.

37. How did you arrive at the decision about who will have custody of your children?

_ Discussion with spouse, ___ Discussion with

children, Discussion with relatives, Consu1tation with my attorney, Professional counseling, Court decision, Other (describe)

Has not been

decided

38. What issues were discussed or are being discussed in deciding who should have custody of your children? Age of children, Sex of children, Wishes of children, Schooling for children, Spec1al health problems, Child care arrangements, Money, Relationships of children to parents, Relationships of parents with other people, Remarriage of either parent, other None of these have been de-

clded or discussed 
39. Which of the following activities of the parents were discussed or are being discussed in deciding who should have custody of your children?

Work schedule, Time away from home, Hous-

ing arrangements, Outside time commitments, Amount of time spent with children, Other ___ None, ___ Have not been discussed or decided

40. Did you ever consider any custody arrangement other than the present one?

Y Yes, _ No

41. What reason(s) would influence you to change the present custody arrangement?

Change in financial ability to provide by either parent, Child neglect or abuse by either parent, Change in elther parent's ability to take care of the children, _C Change in living arrangements by elther parent that affects the children other Haven't decided on custody

arrangement

42. Are you satisfled with the present custody arrangement? __ Yes, _ No, _ Have not decided on custody arrangement

43. Is child support being paid? Yes, No 
44. If no to \#43, will child support be paid in the future?

__ Yes, __ No, ___ I don't know

45. What 1ssues have been or are being discussed regarding child support?

Income of spouse, __ Number of children, Ages of chlldren, __ Opportunity to modify sup-

port in future, Other

Nothing has been discussed

46. Should the parent paying child support be allowed to help decide how the money will be spent?

_ Yes, _ N No, __ I don't know

47. How did you arrive at the decision made regarding child support?

Discussion. with spouse, Consultation with my attorney, Discussion with relatives,

Court decision, Other (describe) Haven't decided regarding

child support

48. Do you agree with the amount that is being paid Yes, N No . - 
49. What issues have been or are being discussed regarding alimony. (spousal support)?

- Income of spouse who w11l pay alimony Income of spouse who will get alimony Child support payments Working capability of spouse who will get alimony Other economic resources of each spouse other (describe) Has not been discussed

50. Has a decision been made regarding alimony (spousal support)?

_ Yes, __ No, __ Not decided

51. How did you arrive at a decision regarding alimony? Discussion with spouse

\section{Consultation with my att} Consultation with my attorney

Court decision

- Discussion with relatives other

Not decided 
52. What do you think is the value of child visitation?

- To maintain a contact between parent and child Parent has a right to visit the children To help the child feel secure and loved Discipline the children

- To help in other decisions concerning the children other (describe)

$$
\text { No value }
$$

53. How did you arrive at a decision regarding visitation arrangements?
Discussed with spouse
Consultation with my attorney
Discussion with relatives
Professional counseling
Court decision
Children's wishes
Other
Have not decided

54. How frequently do you think visitation should take place? Any time, __ About once a week, __ More than
once a week, _ Twice a month, __ Every few months,
On special occasions or vacations only, __ Never 
55. Are you satisfied with present visitation arrangement? _ Yes, __ No, __ Have not decided on visitation arrangement

56. Should the noncustodial parent take an active role in child rearing?

Y Yes, _ No, I _ I don't know

57. If yes to \#56, please check areas in which the noncustodial parent should take an active role.

__ School involvement, ___ Social activities, Dress, __ Driving, _ _ Dating, __ Discipline, Allowance, __ Health, __ Religious training, Use of chlld support money, ___ Other (describe)

None of these

58. Have you noticed any change in your chlldren's behavior since the divorce filing?

Y Yes, __ No, _ I don't know

59. If yes to \#53, please check those areas of change. HEALTH : Eating, Sleeping, Complaints of feeling sick, Fearfulness, other SCHOOL: Attendance, Grades, Classroom behavior RELATIONS WITH : Brothers \& Sisters, Parents, Nelghbors, Playmates \& Friends; Grandparents, Other relatives 
60. Are any of your children in trouble with the police or other juvenile authorities?

__ Yes, _ No, I _ I don't know

61. If yes to \#60, are they under the supervision of the Juventle Court or other agency?

__ Yes, _ No, _ I I don't know

62. If yes to \#61, what agency is providing supervision? __ Juvenile Court, _ Children Services Division, Maclaren School, _Hillcrest School, _ Youth Care Center, __ Other (describe)

63. Have any of your children been in trouble with the police or Juvenile authorities in the past?

__ Yes, _ No, ___ I don't know

64. If yes to \#63, what agency was providing supervision? Juvenile Court, __ Children Services Division, Maclaren School, __ Hillerest School, Youth Care. Center, __ Other (describe)

65. Have any of your chlldren been in any trouble that would ordinarily lead to contact with police or Juvenile authorities?

__ Yes, _ No, __ I don't know 
66. During the divorce proceedings, do you think it would be helpful to have someone sit down with you and your spouse in order to work out a parenting relationship that would be the most beneficlal for your children?

___ Yes, No

67. If such a service were offered by the court, would you attend?

Y Yes, _ No, I I don't know

68. Would you be willing to attend a court sponsored service at this time?

_ Yes, _ N No, __ I don't know

69. Would you be wllling to come if your ex-spouse were also involved?

Y Yes, _ N No, _ I don't know

70. Please write down the name, address and telephone number of a relative or friend who will always know where you can be reached.

Name

First Middle Last

Address:

Number Street City Z1p Code Telephone


APPENDIX II 
I.D. No.

Sex of Parent

Children in Family

Child No. 1

Child No. 2

Child No. 3

Child No. 4

ChIld No. 5

Monthly Income

Working: Full time

Part time

Not working

Religious Preference:

Protestant

Catholic

Jew1sh

Other

None

Type of Problem and Severity

\begin{tabular}{ll} 
Child & Not Severe \\
\hline No. 1 & Severe \\
\hline No. 2 \\
\hline No. 3 \\
\hline No. 4 \\
\hline No. 5
\end{tabular}

